\title{
Kontrol Kecepatan Motor Induksi menggunakan Algoritma Backpropagation Neural Network
}

\author{
MUHAMMAD RUSWANDI DJALAL', KOKO HUTORO², ANDI IMRAN³
}

\author{
${ }^{1}$ Teknik Energi Politeknik Negeri Ujung Pandang \\ 2,3Teknik Elektro (Institut Teknologi Sepuluh Nopember) \\ Email: wandi@poliupg.ac.id
}

\begin{abstract}
ABSTRAK
Banyak strategi kontrol berbasis kecerdasan buatan telah diusulkan dalam penelitian seperti Fuzzy Logic dan Artificial Neural Network (ANN). Tujuan dari penelitian ini adalah untuk mendesain sebuah kontrol agar kecepatan motor induksi dapat diatur sesuai kebutuhan serta membandingkan kinerja motor induksi tanpa kontrol dan dengan kontrol. Dalam penelitian ini diusulkan sebuah metode artificial neural network untuk mengontrol kecepatan motor induksi tiga fasa. Kecepatan referensi motor diatur pada kecepatan $140 \mathrm{rad} / \mathrm{s}, 150 \mathrm{rad} / \mathrm{s}$, dan $130 \mathrm{rad} / \mathrm{s}$. Perubahan kecepatan diatur pada setiap interval 0.3 detik dan waktu simulasi maksimum adalah 0,9 detik. Kasus 1 tanpa kontrol, menunjukkan respon torka dan kecepatan dari motor induksi tiga fasa tanpa kontrol. Meskipun kecepatan motor induksi tiga fasa diatur berubah pada setiap 0,3 detik tidak akan mempengaruhi torka. Selain itu, motor induksi tiga fasa tanpa kontrol memiliki kinerja yang buruk dikarenakan kecepatan motor induksi tidak dapat diatur sesuai dengan kebutuhan. Kasus 2 dengan control backpropagation neural network, meskipun kecepatan motor induksi tiga fasa berubah pada setiap 0.3 detik tidak akan mempengaruhi torsi. Selain itu, kontrol backpropagation neural network memiliki kinerja yang baik dikarenakan kecepatan motor induksi dapat diatur sesuai dengan kebutuhan.
\end{abstract}

Kata Kunci : Backpropagation Neural Network (BPNN), NN Training, NN Testing, Motor.

\begin{abstract}
Many artificial intelligence-based control strategies have been proposed in research such as Fuzzy Logic and Artificial Neural Network (ANN). The purpose of this research was design a control for the induction motor speed that could be adjusted as needed and compare the performance of induction motor without control and with control. In this research, it was proposed an artificial neural network method to control the speed of three-phase induction motors. The reference speed of motor was set at the rate of $140 \mathrm{rad} / \mathrm{s}, 150 \mathrm{rad} / \mathrm{s}$, and $130 \mathrm{rad} / \mathrm{s}$. The speed change was set at every 0.3 second interval and the maximum simulation time was 0.9 seconds. Case 1, without control, shows the torque response and velocity of three-phase induction motor without control. Although the speed of three phase induction motor was set to change at every 0.3 seconds, it would not affect the torque. The uncontrolled three-phase induction motors had poor performance due to induction motor speeds could not be adjusted as needed. Case 2 with backpropagation neural network control, although the speed of three phase induction motor changing at every 0.3 seconds would not affect the torque. In addition, the backpropagation neural network control had a good performance because the speed of induction motor could be adjusted as needed.
\end{abstract}

Key Words : Backpropagation Neural Network (BPNN), NN Training, NN Testing, Motor 


\section{PENDAHULUAN}

Motor induksi merupakan motor listrik yang paling banyak digunakan pada sektor industri baik dalam skala kecil, menengah dan besar. Motor induksi yang digunakan adalah jenis sangkar tupai. Motor induksi memiliki keunggulan seperti konstruksi yang sangat kuat dan sederhana, harga relatif murah, ketahanan dan kehandalan tinggi, efisiensi tinggi, dan biaya pemeliharaan yang rendah selama bertahun-tahun. Oleh karena itu, peran penggunaan motor DC di dunia industri telah tergantikan oleh motor induksi.

Pada motor induksi terdapat parameter yang non-linear yaitu tahanan rotor yang memiliki nilai yang bervariasi untuk kondisi operasi yang berbeda. Hal ini menyebabkan kontrol kecepatan motor induksi menjadi kompleks dan mahal daripada kontrol motor DC. Untuk mendapatkan kecepatan konstan dan meningkatkan kinerja motor induksi maka dibutuhkan suatu kontrol. Beberapa metode kontrol yang digunakan untuk mengendalikan kecepatan motor induksi adalah PI, PID, Fuzzy dan Artificial Neural Network (ANN) (Brandstetter, 2014).

Kontrol kecepatan motor induksi dengan presisi yang tinggi adalah suatu hal yang penting untuk memantau produktivitas dalam dunia industri. Kontrol proporsional integral (PI) adalah kontrol otomatis sederhana dan memiliki kinerja yang baik sehingga banyak digunakan dalam dunia industri. Namun memiliki kelemahan yaitu membutuhkan perhitungan matematik yang rumit dan komplek.

Beberapa metode optimasi berbasis metode konvensional maupun metode cerdas telah banyak digunakan untuk mengoptimasi parameter PID motor DC, diantaranya menggunakan metode konvensional (Waluyo dkk, 2013), dan menggunakan metode cerdas seperti, Artificial Bee Colony (Liao, 2014), Genetic Algorithm (Chen, 2007), Evolutionary Algorithm (He,2007 \& Katal, 2012), Bio-Inspired Algorithm (Bhushan,2011), Bacterial Foraging (Ahuja,2014), Tabu Search (Anant, 2008), Fuzzy Logic (Kumar, 2013), Cuckoo Search (Premkumar,2014) dan Flower (Djalal,2015 \& Lastomo, 2015).

Untuk mengatasi permasalahan di atas, banyak strategi kontrol berbasis kecerdasan buatan telah diusulkan dalam literatur seperti fuzzy dan Artificial Neural Network (ANN). Pada makalah ini diusulkan sebuah metode artificial neural network untuk mengontrol kecepatan motor induksi tiga fasa.

\section{Motor Induksi}

Dalam kontrol V/F, kecepatan motor induksi dikontrol dengan menyesuaikan besaran tegangan dan frekuensi sehingga fluks celah udara dipertahankan pada nilai yang diinginkan pada kondisi steady state. Gambar 1 menunjukkan rangkaian ekivalen motor induksi.

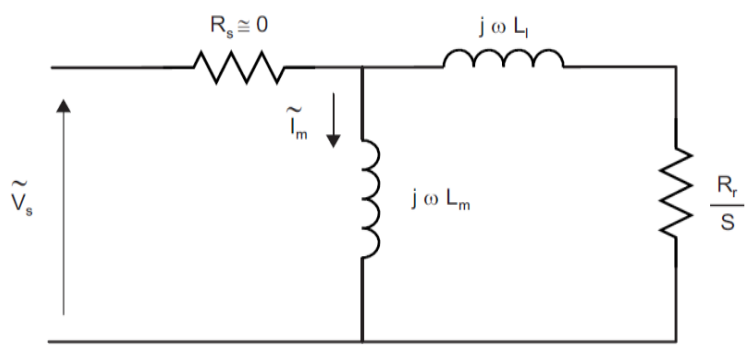

Gambar 1. Rangkaian ekivalen sederhana motor induksi pada kondisi steady state 
Persamaan kecepatan stator, kecepatan rotor, slip, fasor arus magnetisasi, dan arus magnetisasi ditunjukkan pada Persamaan (1)-(5).

$$
\begin{gathered}
N_{s}=\frac{120 f}{P} \\
n_{r}=n_{s}(1-s) \\
S=\frac{n_{s}-n_{r}}{n_{s}} \times 100 \% \\
\tilde{I}_{m}=\frac{\widetilde{V}_{s}}{j \omega L_{m}} \\
I_{m}=\frac{\Lambda_{\mathrm{m}}}{L_{m}}=\frac{V_{s}}{(2 \pi f) L_{m}}
\end{gathered}
$$

Dari Persamaan terakhir, jika V/F dijaga konstan untuk setiap perubahan frekuensi maka fluks tetap konstan dan torka menjadi tergantung frekuensi sumber. Supaya menjaga $\Lambda_{\mathrm{m}}$ tetap konstan maka rasio V/f dijaga konstan pada kecepatan yang berbeda. Gambar 2 menunjukkan profil tegangan stator motor induksi.

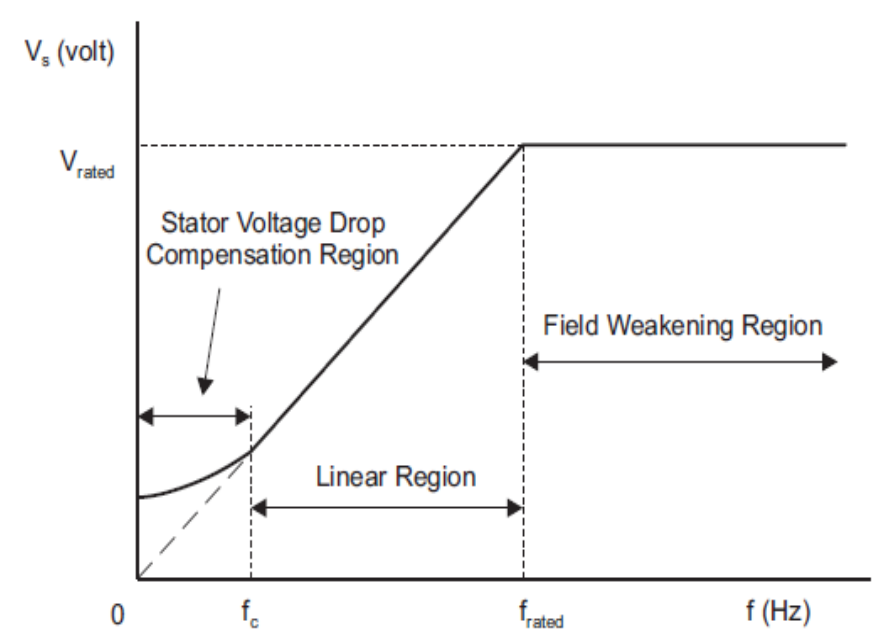

\section{Gambar 2. Profil tegangan stator dengan frekuensi}

Ada 3 range speed pada kontrol V/F yaitu :

1. Pada 0 - fc, drop tegangan stator karena resistansi stator tidak dapat diabaikan dan harus dikompensasi dengan peningkatan Vs.

2. Pada fc - frating, berhubungan V/F konstan. Daerah linier mempresentasikan kuantitas fluks celah udara .

3. Pada rating $f$ lebih tinggi, rasio $V / F$ konstan tidak bisa dipenuhi karena tegangan stator terbatas pada nilai rating supaya menghindari breakdown isolasi pada belitan stator. Daerah ini sering disebut field weakening region. 
Gambar 3 menunjukkan respon torka vs kecepatan motor induksi.

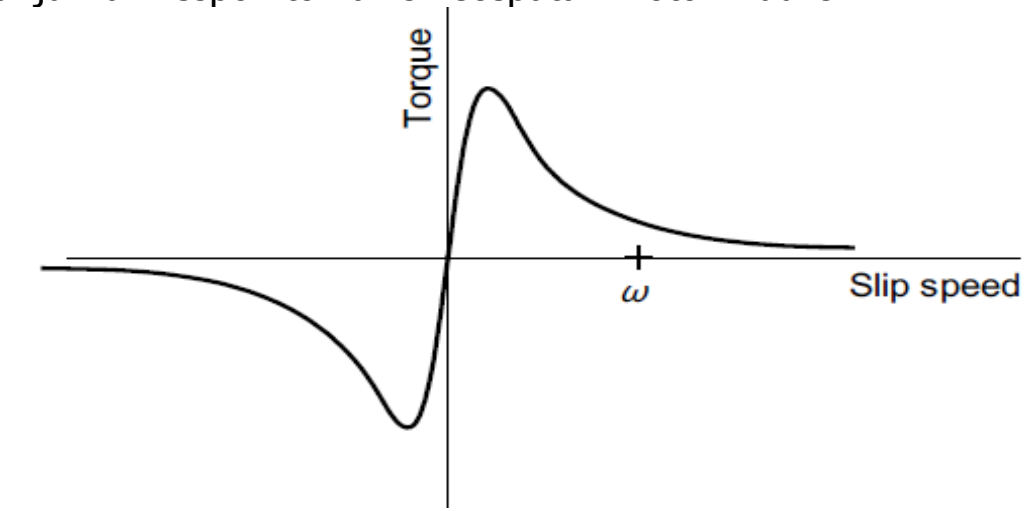

Gambar 3. Torka vs kecepatan slip dengan fluks stator konstan

Karena fluks stator dijaga konstan (tergantung perubahan frekuensi sumber), maka torka tergantung pada slip speed. Dengan mengatur slip maka torka dan kecepatan motor induksi dapat dikontrol dengan prinsip V/F konstan.

\section{METODA PENELITIAN DENGAN BACKPROPAGATION NEURAL NETWORK}

\subsection{Backpropagation Neural Network (BPNN)}

Pada makalah ini, metode backpropagation neural network digunakan untuk mengontrol kecepatan motor induksi tiga fasa. Metode pelatihan yang digunakan pada backpropagation neural network adalah Levenberg Marquardt.

Algoritma Levenberg Marquardt dirancang untuk mendekati kecepatan pelatihan orde kedua tanpa harus menghitung matriks Hessian. Ketika fungsi kinerja memiliki bentuk jumlah kuadrat, maka matriks Hessian dapat diperkirakan dengan menggunakan Persamaan :

$$
H=J^{T} J
$$

Dan gradien dapat dihitung menggunakan Persamaan :

$$
g=J^{T} e
$$

Dengan J adalah matriks Jacobian yang berisi turunan pertama dari network errors yang berhubungan dengan bobot dan bias, dan e adalah vektor network errors. Matriks Jacobian dapat dihitung melalui teknik backpropagation standar yang jauh lebih kompleks daripada komputasi matriks Hessian.

Dengan $\mu$ adalah scalar, pendekatan algoritma Levenberg untuk matriks Hessian dapat menggunakan Persamaan:

$$
X_{k+1}=X_{k}-\left[J^{T} J+\mu I\right]^{-1} J^{T} e
$$

\subsection{Perancangan Backpropagation Neural Network}

Pada proses pelatihan Backpropagation Neural Network, data pelatihan dibagi menjadi tiga :

1. Data pelatihan.

2. Data validasi.

3. Data tes. 
Data sampel yang digunakan berjumlah 90001 dan dibagi menjadi tiga bagian seperti yang ditunjukkan Gambar 4.

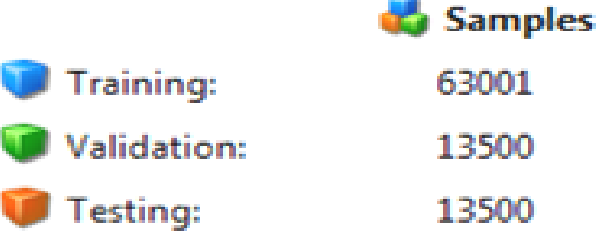

Gambar 4. Pembagian data sampel

Secara umum arsitektur Backpropagation Neural Network terdiri dari tiga bagian yang meliputi masukan, lapis tersembunyi dan keluaran seperti yang ditunjukkan Gambar 5.

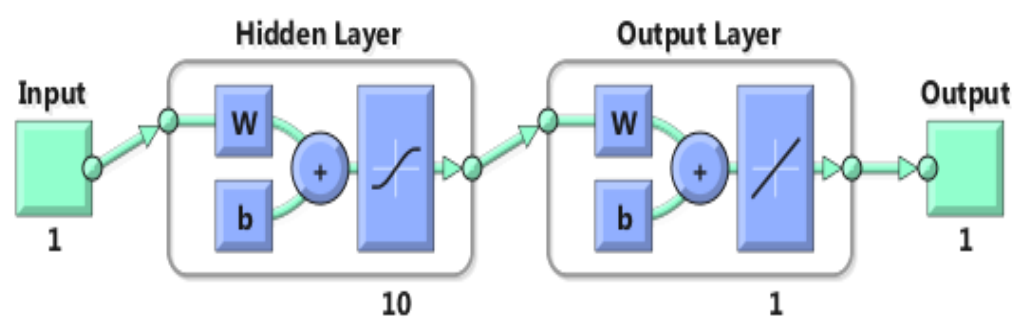

Gambar 5. Arsitektur Backpropagation Neural Network

Proses pelatihan Backpropagation Neural Network ditunjukkan pada Gambar 6.

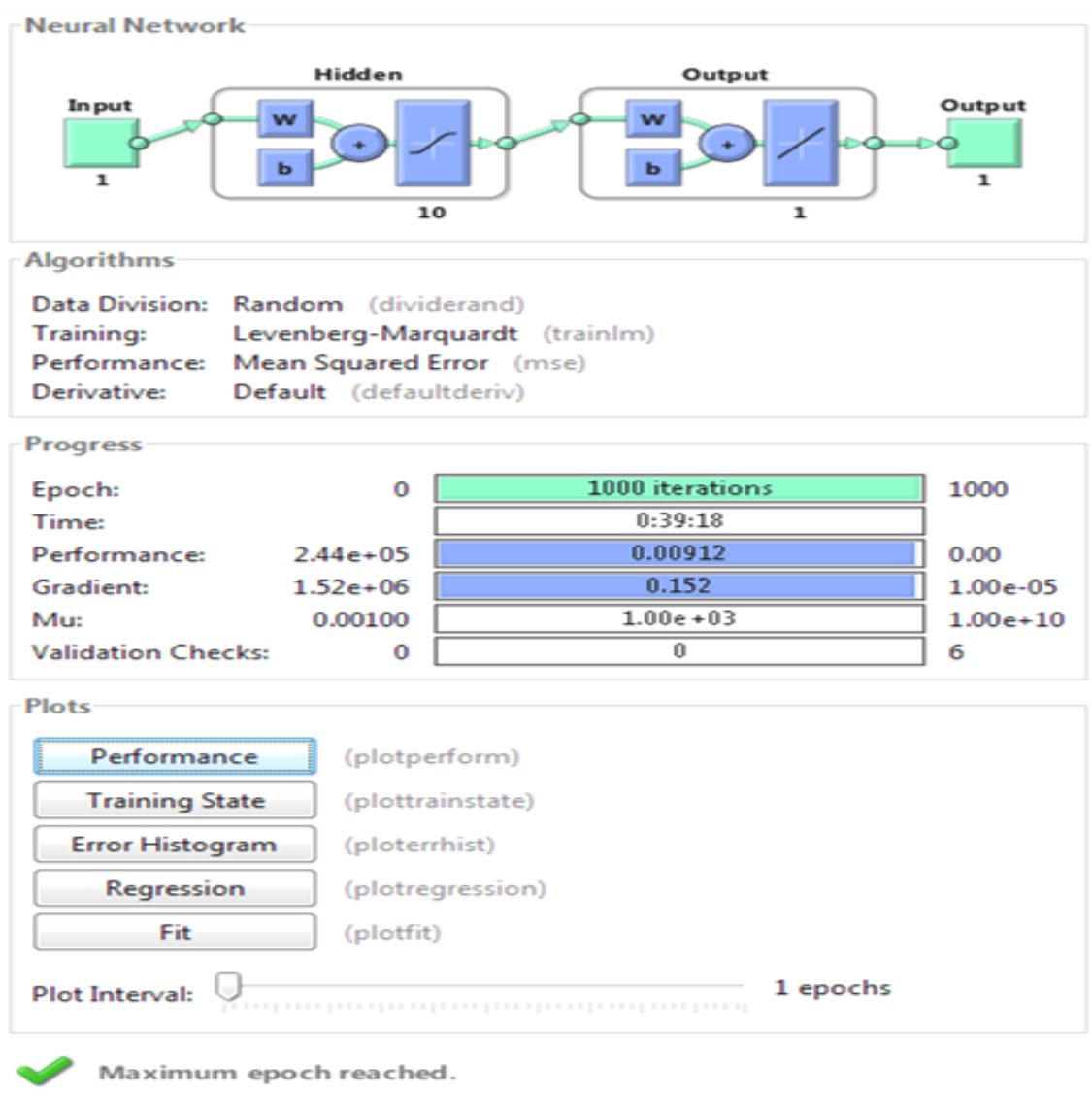

Gambar 6. Proses pelatihan 
Dari proses pelatihan didapatkan epoch sebanyak 1000 iterasi, waktu pelatihan 39 menit 18 detik, performance sebesar 0,00912, gradien sebesar 0,152, dan Mu sebesar 1,00e + 03. Mu adalah parameter kontrol untuk algoritma lavenberg yang digunakan untuk melatih jaringan syaraf tiruan.

\subsection{Hasil Pelatihan}

Hasil pelatihan dari data pelatihan, data validasi dan data tes menghasilkan MSE (Mean Square Error) yang hampir sama (kecil) seperti yang ditunjukkan Gambar 7.

\begin{tabular}{|c|c|c|}
\hline & 8 Samples & $\theta$ MSE \\
\hline (1) Training: & 63001 & $9.11953 \mathrm{e}-3$ \\
\hline (1) Validation: & 13500 & $9.17846 e-3$ \\
\hline (1) Testing: & 13500 & $9.13939 \mathrm{e}-3$ \\
\hline
\end{tabular}

Gambar 7. Hasil pelatihan

Setelah hasil pelatihan sukses dengan MSE yang kecil maka secara otomatis akan menghasilkan blok diagram backpropagation neural network. Blok diagram ini akan dimasukkan ke dalam sistem yang telah dibuat. Gambar 8 menunjukkan blok diagram neural network.

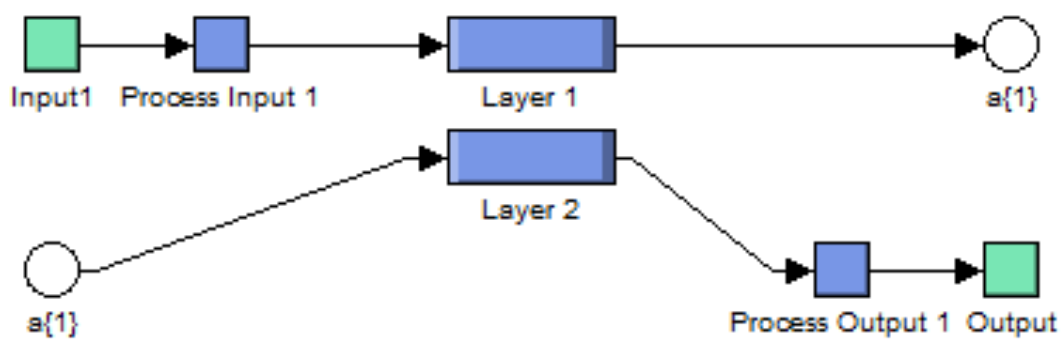

Gambar 8. Blok diagram backpropagation neural network

\section{HASIL DAN ANALISIS}

\subsection{Parameter Motor Induksi}

$M A T L A B$ / Simulink digunakan untuk mensimulasikan respon torsi dan kecepatan dari motor induksi tiga fasa. Tabel 1 dan Tabel 2 menunjukkan parameter motor induksi untuk penelitian.

Tabel 1. Parameter motor induksi

\begin{tabular}{|l|l|}
\hline Preset model: & $5.4 \mathrm{HP}(4 \mathrm{KW}), 400 \mathrm{~V}, 60 \mathrm{~Hz}, 1430 \mathrm{RPM}$ \\
\hline Rotor type: & Squirrel-cage \\
\hline Stator resistance: & $1.405 \mathrm{ohm}$ \\
\hline Stator inductance: & $0.005839 \mathrm{H}$ \\
\hline Rotor resistance: & $1.395 \mathrm{ohm}$ \\
\hline Rotor inductance: & $0.005839 \mathrm{H}$ \\
\hline Mutual inductance: & $0.1722 \mathrm{H}$ \\
\hline Inertia: & $0.0131 \mathrm{~kg} \cdot \mathrm{m}^{2}$ \\
\hline
\end{tabular}


Tabel 2. Parameter inverter dan filter

\begin{tabular}{|c|c|}
\hline Filter & Satuan \\
\hline Resistance & $1 \mathrm{ohm}$ \\
\hline Inductance & $1 \mathrm{e}-3 \mathrm{H}$ \\
\hline Capacitance & $1 \mathrm{e}-3 \mathrm{~F}$ \\
\hline Inverter using IGBT & Satuan \\
\hline Internal resistance & $1 \mathrm{e}-3 \mathrm{ohm}$ \\
\hline Snubber resistance & $1 \mathrm{e} 5 \mathrm{ohm}$ \\
\hline Snubber capacitance & $\mathrm{Inf}$ \\
\hline
\end{tabular}

\subsection{Studi Kasus}

Kecepatan referensi motor diatur pada kecepatan $140 \mathrm{rad} / \mathrm{s}, 150 \mathrm{rad} / \mathrm{s}$, dan $130 \mathrm{rad} / \mathrm{s}$. Perubahan kecepatan diatur pada setiap interval 0.3 detik dan waktu simulasi maksimum adalah 0,9 detik. Skema simulasi dapat dilihat pada studi kasus 1 dan studi kasus 2.

\subsubsection{Studi Kasus 1}

Gambar 9 menunjukkan blok diagram untuk motor induksi tanpa control.

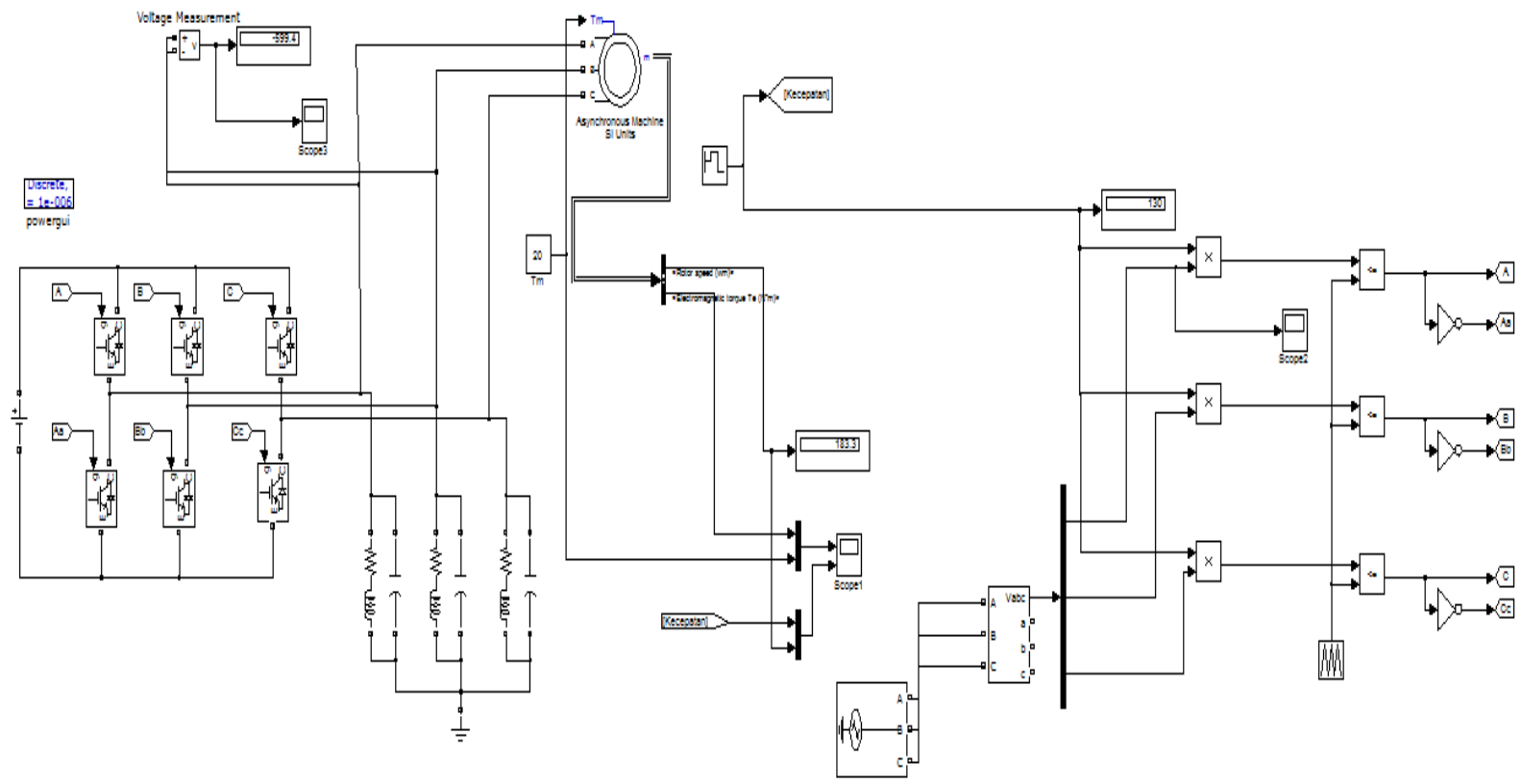

Gambar 9. Blok diagram sistem tanpa control

Gambar 10 menunjukkan respon torka motor induksi tanpa control.

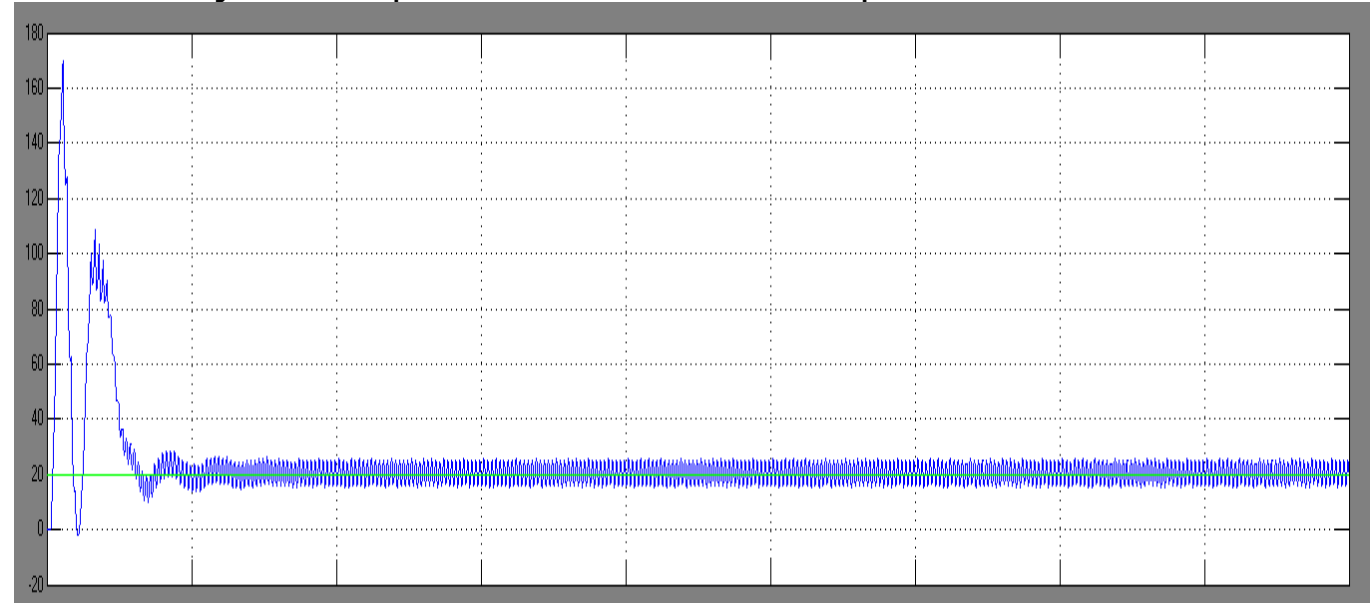

Gambar 10. Respon torsi motor induksi tanpa control 
Gambar 11 menunjukkan respon kecepatan motor induksi tanpa control.

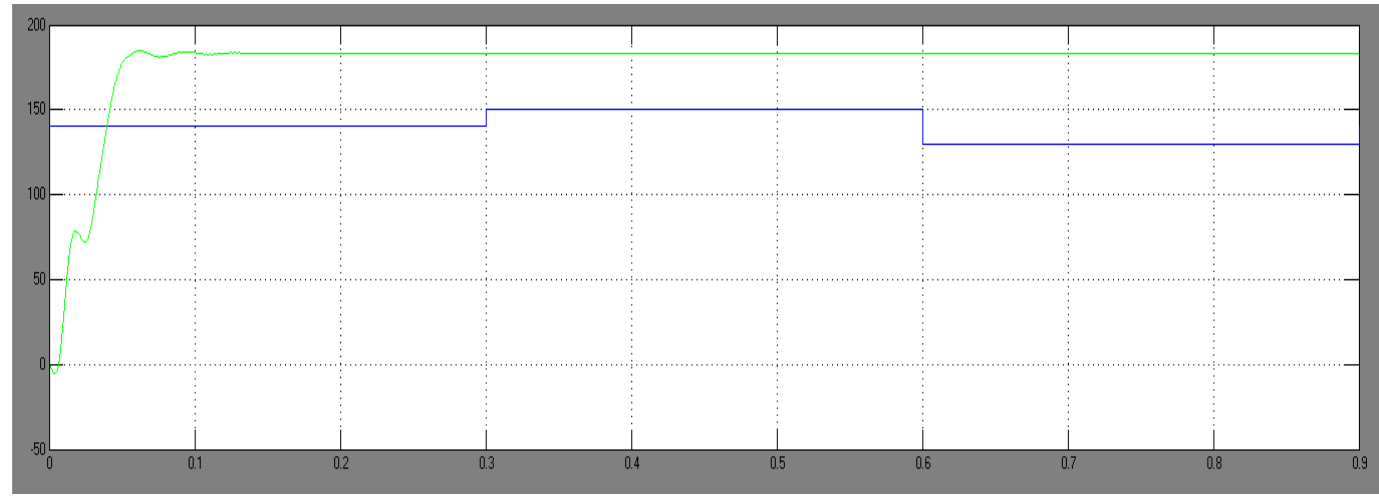

Gambar 11. Respon kecepatan motor induksi tanpa control

Meskipun kecepatan motor induksi tiga fasa diatur berubah pada setiap 0,3 detik, ia tidak akan mempengaruhi torka. Selain itu, motor induksi tiga fasa tanpa kontrol memiliki kinerja yang buruk dikarenakan kecepatan motor induksi tidak dapat diatur sesuai dengan kebutuhan. Hasil simulasi yang bersumber dari Gambar 10 dan Gambar 11 direpresentasikan pada Tabel 3.

Tabel 3. Hasil simulasi tanpa kontrol

\begin{tabular}{|c|c|c|c|}
\hline Parameter & $\begin{array}{c}\text { Kecepatan } \\
\text { Referensi 1 }\end{array}$ & $\begin{array}{c}\text { Kecepatan } \\
\text { Referensi 1 }\end{array}$ & $\begin{array}{c}\text { Kecepatan } \\
\text { Referensi 1 }\end{array}$ \\
\hline Kecepatan referensi (rad/s) & 140 & 150 & 130 \\
\hline Kecepatan terukur (rad/s) & 183.5 & 183.5 & 183.5 \\
\hline Waktu pada saat terjadi perubahan kecepatan (s) & 0 & 0.3 & 0.6 \\
\hline Waktu yang dibutuhkan untuk steady state (s) & 0.2 & 0.2 & 0.2 \\
\hline
\end{tabular}

\subsubsection{Studi Kasus 2}

Gambar 12 menunjukkan blok diagram system control motor induksi dengan backpropagation neural network.

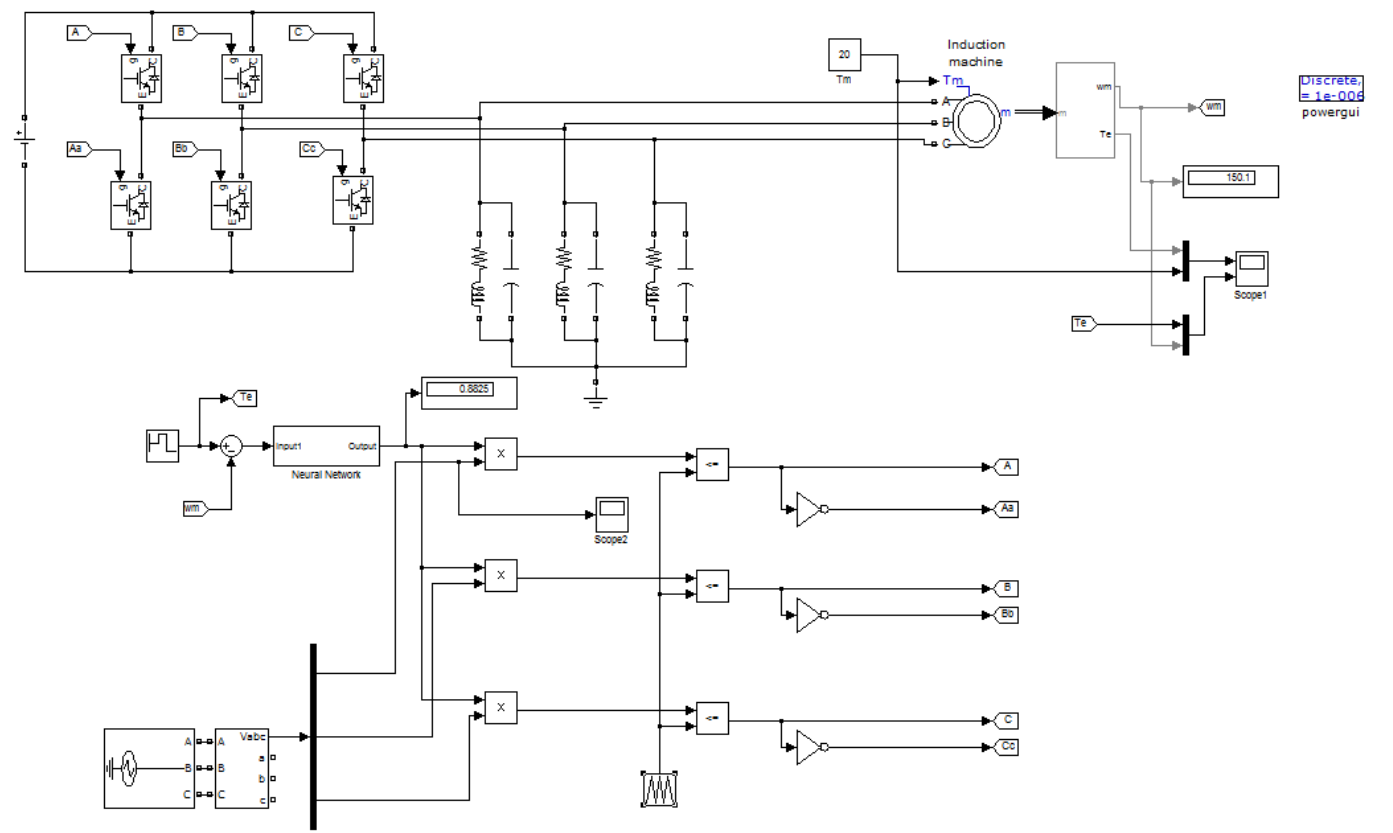

Gambar 12. Blok diagram sistem dengan kontrol backpropagation neural network 
Gambar 13 menunjukkan respon torka motor induksi dengan contro/BPNN.

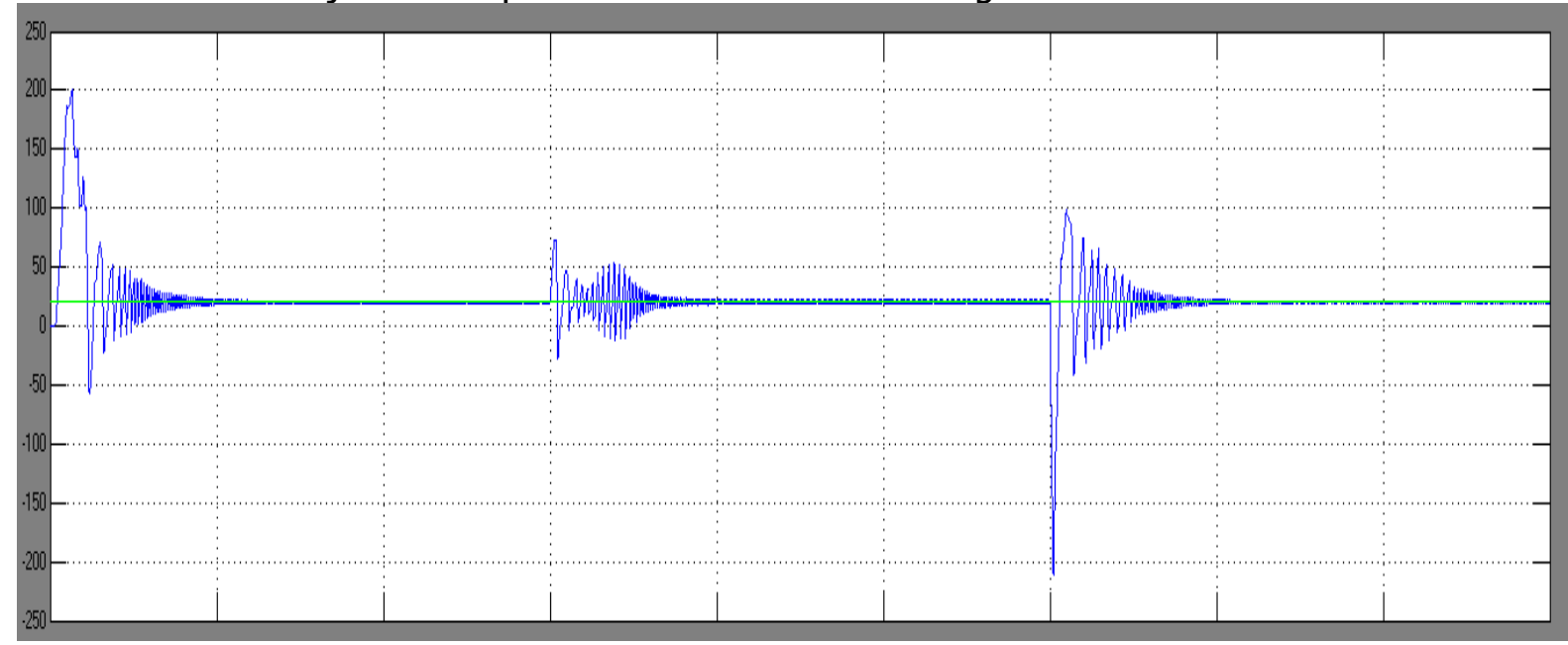

Gambar 13. Respon torka motor induksi dengan kontrol backpropagation neural network

Gambar 13 menunjukkan respon kecepatan motor induksi dengan contro/BPNN.

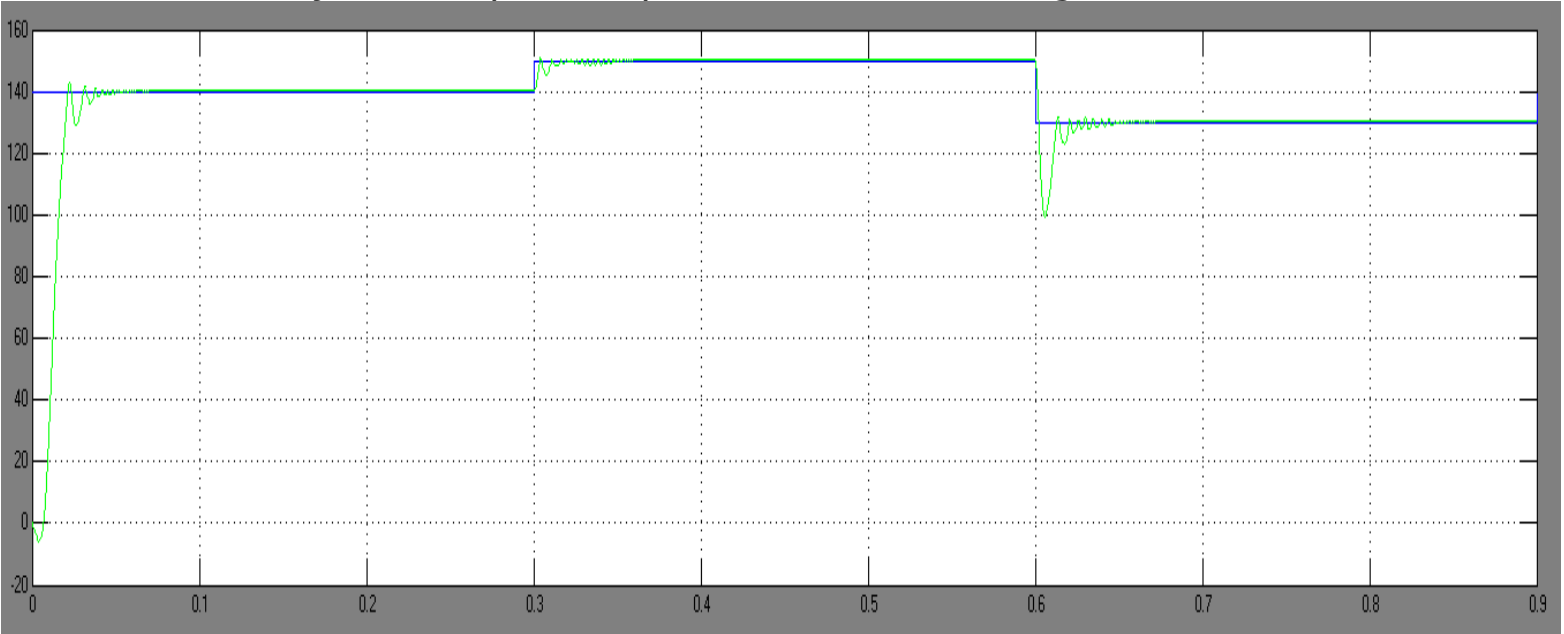

Gambar 14. Respon kecepatan motor induksi dengan kontrol backpropagation neural network

Meskipun kecepatan motor induksi tiga fasa berubah pada setiap 0.3 detik, maka ia tidak akan mempengaruhi torsi. Selain itu, kontrol backpropagation neural network memiliki kinerja yang baik dikarenakan kecepatan motor induksi dapat diatur sesuai dengan kebutuhan. Hasil simulasi yang bersumber dari Gambar 13 dan Gambar 14 direpresentasikan pada Tabel 4.

Tabel 4. Hasil simulasi menggunakan kontrol backpropagation neural network

\begin{tabular}{|c|c|c|c|}
\hline Parameter & $\begin{array}{c}\text { Kecepatan } \\
\text { Referensi 1 }\end{array}$ & $\begin{array}{c}\text { Kecepatan } \\
\text { Referensi 1 }\end{array}$ & $\begin{array}{c}\text { Kecepatan } \\
\text { Referensi 1 }\end{array}$ \\
\hline Kecepatan referensi (rad/s) & 140 & 150 & 130 \\
\hline Kecepatan referensi (rad/s) & 140 & 150 & 130 \\
\hline Kecepatan terukur (rad/s) & 0 & 0.3 & 0.6 \\
\hline Waktu pada saat terjadi perubahan kecepatan (s) & 0,085 & 0,385 & 0,685 \\
\hline
\end{tabular}




\section{KESIMPULAN}

Dari simulasi yang telah didemontrasikan bahwa backpropagation neural network dapat digunakan sebagai kontrol untuk mengatur kecepatan motor induksi sesuai nilai referensi yang diberikan. Case 1 menunjukkan Motor induksi tiga fasa tanpa kontrol memiliki kinerja yang buruk dikarenakan kecepatan motor induksi tidak dapat diatur sesuai dengan kebutuhan berdasarkan set poin $140 \mathrm{rad} / \mathrm{s}, 150 \mathrm{rad} / \mathrm{s}$ dan $130 \mathrm{rad} / \mathrm{s}$, dengan kecepatan yang terukur masing-masing 183,5 rad/s, dengan settling time masing-masing sebesar 0,2 s. Motor yang menggunakan kontrol backpropagation neural network memiliki kinerja yang lebih baik daripada motor tanpa kontrol dikarenakan kecepatan dapat diatur sesuai kebutuhan dunia industri. Case 2 menunjukkan hasil yang lebih baik dengan kecepatan terukur masing-masing sama dengan setpoint $140 \mathrm{rad} / \mathrm{s}, 150 \mathrm{rad} / \mathrm{s}$ dan $130 \mathrm{rad} / \mathrm{s}$, dengan settling time selama 0,085 s, 0,385 s dan 0,685 s.

\section{DAFTAR RUJUKAN}

Waluyo, W., Fitriansyah, A., \& Syahrial, S. (2013). Analisis Penalaan Kontrol PID pada Simulasi Kendali Kecepatan Putaran Motor DC Berbeban menggunakan Metode Heuristik. Jurnal Elkomika, 1(2).

P. Brandstetter. (2014). Sensorless Control of DC Drive Using Artificial Neural Network, Journal of Applied Sciences, 11(10).

Wudai Liao. (2014). Optimization of PID Control for DC Motor Based On Artificial Bee Colony Algorithm.

D. Chen, K. Fang, and Q. Chen. (2007). Application of genetic algorithm in PID parameters optimization. Microcomputer Information, 23(3): 35-36.

H. He and F. Qian. (2014). The PID parameter tuning based on immune evolutionary algorithm, Microcomputer Information, 27(5): 1174-1176.

Nitish Katal. (2012). Optimal Tuning of PID Controller for DC Motor using Bio-Inspired Algorithms. International Journal of Computer Applications.

Bharat Bhushan. (2011). Adaptive control of DC motor using bacterial foraging algorithm. Applied Soft Computing sciencedirect".

Ashu Ahuja. (2014). Design of fractional order PID controller for DC motor using evolutionary optimization techniques. WSEAS Transactions on Systems and Control.

Anant Oonsivilai. (2008). Optimum PID Controller tuning for AVR System using Adaptive Tabu Search, 12th WSEAS International Conference on COMPUTERS, Heraklion, Greece, July 23-25.

Umesh Kumar Bansal. (2013). Speed Control of DC Motor Using Fuzzy PID Controller, Advance in Electronic and Electric Engineering. 
K. Premkumar. (2015). Fuzzy PID supervised online ANFIS based speed controller for brushless dc motor. Sciencedirect. Neurocomputing.

M.R.Djalal, D. Ajiatmo, A. Imran, I. Robandi. (2015). Desain Optimal Kontroler PID Motor DC Menggunakan Cuckoo Search Algorithm, Seminar Nasional Teknologi Informasi dan Aplikasinya (SENTIA) Politeknik Negeri Malang.

D.Lastomo, M.R.Djalal, Widodo, I.Robandi. (2015). Optimization of PID Controller Design for DC Motor Based on Flower Pollination Algorithm, The 2015 International Conference on Electrical, Telecommunication and Computer Engineering (ELTICOM 2015). 